\title{
FEDERALISM AND UNIFORMITY OF LAWS: THE CANADIAN EXPERIENCE
}

\author{
E. E. PALMER*
}

\section{INTRODUCTION}

Diversity of legislation is inevitable in a federal state, the degree of this diversity depending in large part on various economic and societal factors such as the political and cultural homogeneity of the population, patterns of trade, and the like. The diversive effect of these factors cannot be nullified but only ameliorated by legal institutions and practices. Unfortunately, few federations have more pressures against uniformity than Canada. Two major cultures, the English and the French, each with different religions and systems of law, oppose each other; ${ }^{1}$ geography divides the country into five major areas, each with different and often competing economies; ${ }^{2}$ and political philosophies from Socialism on the left to Social Credit on the far right have all achieved popular acceptance at one time or another. Thus, the Canadian experience in striving for uniformity in law has special relevance to the present symposium. This paper will attempt to outline the history of these efforts in the areas of division of legislative competence, enactment of legislation, and the role of the courts in obtaining uniformity.

\section{Centralization of Legislative Power}

If the key to uniformity of laws is centralization of legislative power, then by definition a federation such as Canada can hope for only partial success in this field. However, by placing the vast bulk of important legislative competence in the hands of the federal government, a relatively high degree of uniformity can be obtained. Prompted by the Civil War in the United States, which they attributed to a weak central government, creators of the Canadian constitution attempted to achieve this

* Associate Professor of Law, University of Western Ontario, London, Ontario, Canada. B.A. 1955, William and Mary College; M.A. I956, Yale University; LL.B. 1959, LL.M. 1960, University of Toronto; Barrister and Solicitor, Law Society of Upper Canada. Author, [with Professor F. E. LaBrie] CAsEs AND MAterials on THE LAW of CoMpanies (I96I), as well as other articles in legal periodicals.

1 This difference is seen clearly in Saumur v. Quebec, [1953] 2 S.C.R. 299, [I953] 4 D.L.R. 641, where an Anglo-Saxon majority of the Supreme Court of Canada, obviously in favour of an "Open Society," was faced by the problem of where to draw limits on Quebec's power to repress insulting and abusive attacks on the Roman Catholic Church. See also Laskin, Oar Civil Liberties-The Role of the Supreme Court, 4I QUEEN's QUarTerly 455 (1955), and McWhinney, Mr. Justice Rand's "Rights of the Canadian Citizen"-T'he "Padlock Case," 4 WAYNe L. Rev. II5, I21 (I958).

${ }^{2}$ Generally, these are: (i) the largely depressed Maritimes who depend on fishing and mixed agriculture; (ii) Quebec with mining and big business; (iii) Ontario, the hub of Canadian economic life and by far the wealthiest province; (iv) the Prairie Provinces, rich in petroleum and wheat; and (v) British Columbia, dependent on lumbering and the Pacific. Each of these areas are divided by natural phenomenn such as the Rocky Mountains or large uninhabited areas or, in the case of Ontario and the Maritimes, by the alien culture of Quebec. 
goal, ${ }^{3}$ and at first reading, Canada's constitution, the British North America Act, ${ }^{4}$ would seem to provide this. In contrast to the United States this act deals with the legislative competence of both the central and provincial governments. Generally, this division is found in sections ninety-one and ninety-two, the latter section listing sixteen heads of provincial power, the former assigning the federal government the power to make laws "for the peace, order and good government of Canada" as shown by thirty specific examples of power as well as the residual power to deal with all matters not specifically assigned to the provinces. Because of this latter stipulation and the specific enumeration of "the regulation of trade and commerce" as a federal head of power, ${ }^{5}$ it would seem obvious that the central government would have jurisdiction to deal with the major part of Canada's commercial life. It is, therefore, ironic that such has not been the case and that, generally, there is so little uniformity in Canadian law.

The main reason for this failure lies in the interpretation of the constitution by the Privy Council, which was the final court of appeal in Canada until $19490^{6}$ By stressing the "property and civil rights" clause of section ninety-two rather than "trade and commerce" power in section ninety-one, for example, federal legislation regulating insurance was held ultra vires, i.e., unconstitutional. Also, by this technique, provincial control of commercial activity was extended at the expense of distortion of the plain meaning of the constitution and, ultimately, of uniformity of laws in these areas. $^{8}$ Thus, matters such as labor relations, ${ }^{9}$ unemployment insurance, ${ }^{10}$ and securities regulation ${ }^{11}$ passed, in fact, into provincial hands. The only way out has been

${ }^{3}$ See MacTavish, Uniformity of Legislation in Canada-An Outline, 25 CAN. B. REv, 36, 36-42 (1947). For a fuller examination of this point, see generally H. MCD. Clokse, Canadian Government and Politics (I944), and J. A. Corro, Democratic Government and Politics (I946).

30 Vict. c. 3 (U.K. 1867 ).

ᄃId. $\$ 9 \mathrm{r}(2)$. Other examples of significant federal heads of power are: a plenary power of taxation as opposed to the provinces' limited power of direct taxation "for provincial purposes" ( $\$ 9 \mathrm{I}(3))$, control over navigation and shipping ( $(9 \mathrm{I}(\mathrm{ro}))$, banking $(\S 9 \mathrm{I}(\mathrm{I} 5, \mathrm{I} 6)$ ), bills of exchange and promissory notes ( $(9 \mathrm{I}(\mathrm{I} 8)$ ), interest $(\$ 9 \mathrm{I}(\mathrm{I} 9))$, bankruptcy ( $\$ \mathrm{gI}(2 \mathrm{I}))$, patents and copyrights ( $\$ 9 \mathrm{I}(22,23)$ ), marriage and divorce ( $(9 \mathrm{I}(26))$, and the criminal law $(\$ 9 I(27))$.

- The Supreme Court Act, $1_{3}$ Geo. 6, c. 37 (I949). The right of the Dominion to abolish these appeals was indicated in A.-G. for Ont. v. A.-G. for Can., [I947] A.C. I27, [1947] I D.L.R. 80I (P.C.). See Gordon, Farris \& Scott, Abolition of Appeals to the Privy Council: A Symposium, 25 CAN. B. REv. 557 (1947).

7 A.-G. for Can. v. A.-G. for Alta., [19I6] A.C. 588, 26 D.L.R. 288 (P.C.)

"An excellent book on the development of the "trade and commerce" power in Canada is A. SMITH, The Commerce Power in Canada and the United States (1963). On this point, see also Lederman, A Comparison of Principal Elements of the Legal Systems and Constitutions of Canada and the United States, II AM. J. CoMp. Law 286, 288-89 (I962).

- Toronto Electric Commissioners v. Snider, [I925] A.C. 396, [I925] 2 D.L.R. 5 (P.C.). Thus, the Dominion has been left with the power to deal with labor relations only in so far as necessary for the control of industries over which the Dominion has exclusive jurisdiction, such as railroads or uranium mining. In other areas, even though a company may have plants in each province, its labor relations depend on the legislation of the particular province where the individual plants are located.

${ }^{10}$ A.-G. for Can. v. A.-G. for Ont. [1937] A.C. 326, [1937] I D.L.R. 673 (P.C.). This case was reversed by the British North America (No. 2) Act, 13 Geo. 6, c. 81 (U.K. I949); and "unemployment insurance" is now included as $\$ 9 \mathrm{I}(2 \mathrm{~A})$ of the British North America [hereinafter cited as B.N.A.] Act.

${ }^{11}$ Lynburn y. Maryland, [1932] A.C. 3I8, [I93I] 2 D.L.R. 698 (P.C.). 
by constitutional amendment, and that, due to its inherent difficulty, has only once been successfully used. ${ }^{12}$

When dealing with other heads of power the Privy Council also showed its desire to expand provincial legislative authority, always to the detriment of commercial life in Canada. ${ }^{13}$ This proclivity was most clearly shown in the area of company law. Besides the mutilation of controls over securities mentioned above, ${ }^{14}$ this court also grotesquely twisted the constitutional provisions relating to the authority to incorporate businesses. Under the British North America Act the federal power to incorporate was found under the trade and commerce and residual power, ${ }^{15}$ and a limited power to incorporate companies "with provincial objects" was given to the provinces. ${ }^{16}$ Naturally enough, Canadian courts interpreted this latter clause to mean that the provincial power to incorporate was limited both territorially and to objects over which the provinces were given legislative control. ${ }^{17}$ The Privy Council completely reversed this position in I9x6 in the Bonanza Creek case. ${ }^{18}$ There a company incorporated by letters patent in Ontario was carrying on gold mining activities in the Yukon. While before the Canadian courts it was held that Ontario did not have the power to create a corporation with this capacity, ${ }^{10}$ the Privy Council reached the opposite result. Viscount Haldane, who gave the opinion of the Committee, stated that incorporation by letters patent was not an exercise of power under section 92(II), but rather an exercise of the prerogative power of the Crown vested in the province. In other words, Ontario had created a common law company similar to that in the Sutton's Hospital Case ${ }^{20}$ and so not subject to the ultra vires rule. As a result of this decision not only could provincial companies carry on their main business beyond their territorial boundaries in almost any type of business they wished, ${ }^{21}$ but also Canada was left in the position where six of the eleven jurisdictions used systems of incorporation basically different from the other five. ${ }^{22}$

${ }^{12}$ See supra note ro. Another possible constitutional method of gaining uniformity is by use of the federal government's power of disallowance of provincial legislation found in the B.N.A. Act, $\$ \$ 55-57$ and 90. Unfortunately, such a course of action is politically impossible. See, on this problem, G. V. Laforest, Disallowance and Reservation of Provincial Legislation (1955).

${ }^{13}$ The Privy Council became the bête noire of Canadian constitutional lawyers due to this approach. For examples of their criticism, see Laskin, "Peace, Order and Good Government" Re-cxamined, 25 CAN. B. Rev. I054 (1947); LaBrie, Canadian Constitutional Interpretation and Legislative Review, 8 U. Toronto L.J. 298 (1950); Scott, The Special Nature of Canadian Federalism, 13 CaN. J. Ec. \& Pol. Sci. 13 (1947); MacDonald, The Constitution in a Changing World, 26 CAN. B. REv. 2I (1948).

14 Supra note 1I. On this point, see J. P. Williamson, Securaties Regulation in Canada (x960).

${ }^{26}$ John Deere Plow Co. v. Wharton, [1915] A.C. 330, I8 D.L.R. 353 (P.C. 1914).

${ }^{20} \mathrm{Sec}$. $92(\mathrm{II})$.

${ }^{17}$ International Home Purchasing Contract Co. v. Reg. Joint Stock Companies, 5 ALts. L.R. 374, 3 West. Weekly R. 806 (S.C. I9I2); In re Grain Marketing Act, 25 SAsk. L.R. 273, [1931] 2 West. Weekly R. 146 (C.A.).

${ }_{18}$ Bonanza Creek Gold Mining Co. v. The King, [19r6] I A.C. 566, 26 D.L.R. 273 (P.C. 1916).

${ }^{10}$ 50 Can. S.C.R. 534, 2 I D.L.R. I23 (I9I5); affirming the Exchequer Court of Canada (unreported).

20 The Case of Sutton's Hospital, Io Co. Rep. 23a, 77 Eng. Rep. 960 (K.B. I6r5).

${ }^{21}$ For example, $\$ 9 \mathrm{r}(\mathrm{r} 5)$ of the B.N.A. Act specifically gives the federal government the exclusive power to incorporate banks.

32 The six governments incorporating by letters patent are the Dominion, Manitoba, Ncw Brunswick, Ontario, Prince Edward Island, and Quebec; the five incorporating by registration are Alberta, British 
The impact of this decision on Canadian company law and lawyers was immense ${ }^{23}$ and rekindled interest in attempts to provide uniformity in this area of law, for as early as rgro efforts had been made to establish a Model Companies Act; ${ }^{24}$ and Canada had also been a participant in the Imperial Conference on Uniform Company Legislation. ${ }^{25}$ These renewed attempts did not achieve auspicious results. For example, at one point the Dominion Companies Act of I934 was to be the model for all companies acts in the country, and all provinces were asked to make suggestions to its drafters at the Dominion-Provincial Conferences in 1933 and 1934. None availed themselves of this offer, ${ }^{26}$ nor was the final product the pattern of any future legislation. ${ }^{27}$ However, at the 1935 Dominion-Provincial Conference a Committee on Uniform Company Law as established ${ }^{28}$ which was the direct forerunner of a present committee studying this problem. After twenty-seven years a second draft of a proposed act has finally been completed. ${ }^{29}$

The difficulties these committees have faced indicate some of the vexatious problems of uniformity of law in Canada. After thirty years of work the committees which have worked on this problem have achieved unanimity only on a few basic issues. For example, at one time it was argued that it would be impossible to maintain uniform companies acts in eleven jurisdictions due to the problem of amendments necessary to keep company law in tune with changing business conditions. Therefore, it was proposed that the British North America Act be amended to give the federal government the sole power to incorporate companies. ${ }^{30}$ It seems that this suggestion has been emphatically rejected and the question of amendments conveniently forgotten. ${ }^{31}$ Similarly, there was at one time considerable debate as to

Columbia, Newfoundland, Nova Scotia, and Saskatchewan. Besides the application of the ultra vires rule, a basic difference between the two systems is that the former system is controlled ministerially while the courts play a larger role in the administration of the latter. See, for a discussion of this point, Wegenast, Memorandum re Uniformity in Company Law, 37 CAN. L. T. 105, ro8-09 (1917). Again, the contractual base of the registration system is completely wiped out with the interposition of the prerogative fiction.

${ }^{n B}$ Few cases have created the degree of alarm and indignant reaction in Canadian law than did Lord Haldane's judgment in this one. See, e.g., F. W. Wegenast, The Law of Canadian Companies (I93I), and E. R. Cameron, Canadian Companies and the Judicial Commitre (I922). The many important articles discussing the implications of this case are found listed in F. E. LABRIE \& E. E. PALMER, CAsEs AND Materials on the Law of Companies at iv-28 (I96r). Similar disagreement has found expression by the judges. See, for example, Hodgins, J. A., in Waterous Engine Co. v. Capreol, 52 ONT. L.R. 247, 255 (1923), 3 D.L.R. 575, 588 (C.A. I922).

24 See Smith, Uniform Company Law in Canada, 16 CAN. B. REv. joI (I938).

${ }^{25}$ See Garrett, Phases of Company Law in Canada, 37 CaN. L. T. 706 (19I7).

${ }^{36}$ See Richardson, Company Law: 1923-47, 26 CAN. B. Rev. I85, 187 (1948).

${ }^{27}$ See Smith, supra note 24 , at 702 .

18 See McTavish, supra note 3.

20 See Spectal Committee on Uniform Contpanies Act, Revised Draft Uniform Acts (Memorandum and Articles and LetTers Patent) ( 1960 ); partially reproduced in CCH Dominion ComPANIES LAW REPORTS (Special Report No. I72, May 9, I962).

${ }^{\circ}$ See generally, Gurd, The Ideal Company Law for Canada, 5 CAN. B.-Rev. 733 (I927); and Staunton, Some Suggestions Regarding Company Legislation, 37 CAN. L.T. 346 (19I7). In return for such a change in the constitution, incorporation fees were to be split according to an arranged formula.

2 Report of the Royal Comaission on Dominion-Provincial Relations 56 (1940). 
whether to incorporate all companies by registration ${ }^{32}$ or by letters patent; ${ }^{33}$ but in I937 there was agreement that it was not necessary to have uniformity in the method of incorporation. ${ }^{34}$ At the same time it was decided that, generally, uniformity should only be sought in securities legislation and the internal management of companies. However, by refusing to seek uniformity in either of the two matters first mentioned above, there seems to be an admission that all that was wanted-and certainly all that could be achieved-was partial uniformity in Canadian company legislation: it is nowhere made clear how similar results could be obtained from two basically different systems of incorporation, nor how the hurdle of amendments was to be overcome. While one may whole-heartedly agree with the observation that a "uniform company law is desirable and ... is likely to receive more attention in the future, ${ }^{, 35}$ in the present circumstances one must have similar sentiments for the statement that a model act in Canada is "foredoomed to failure."36

Even given these limitations, it is important to note the Committee achieved little. It produced a draft act based, for the most part, on the present Dominion Companies $\mathrm{Act}^{37}$ and the Ontario Corporations Act. ${ }^{38}$ This in itself might be important, for at present some Canadian acts, such as the Manitoba Companies Act, ${ }^{80}$ are extremely lengthy (having separate sections for the incorporation of cemetery companies, for example); others, such as the Prince Edward Island Companies Act, ${ }^{40}$ are reproduced in only a few dozen pages; and an exact counterpart of the British Joint Stock Companies Act of $1862^{41}$ can be found in the Newfoundland Companies Act. ${ }^{42}$ Thus, such an act would avoid some of the worst extremes of company legislation in Canada. The Committee has also gone beyond merely synthesizing the two acts and has introduced some entirely new legislation in Canada to facilitate the carrying on of business in pursuance of it. For example, the proposed act would permit a private company to purchase for cancellation any of its common shares at a price not exceeding the market value; in the case of a public company only its common shares held by employees can be so dealt with. Again, to eliminate the practice of having some directors holding a minimum of shares in the company in order to qualify for that position, the Uniform Companies Act would permit a company to pass a by-law stating that directors of a company need not be shareholders. Similar changes are scattered throughout the draft act. ${ }^{43}$ However, this

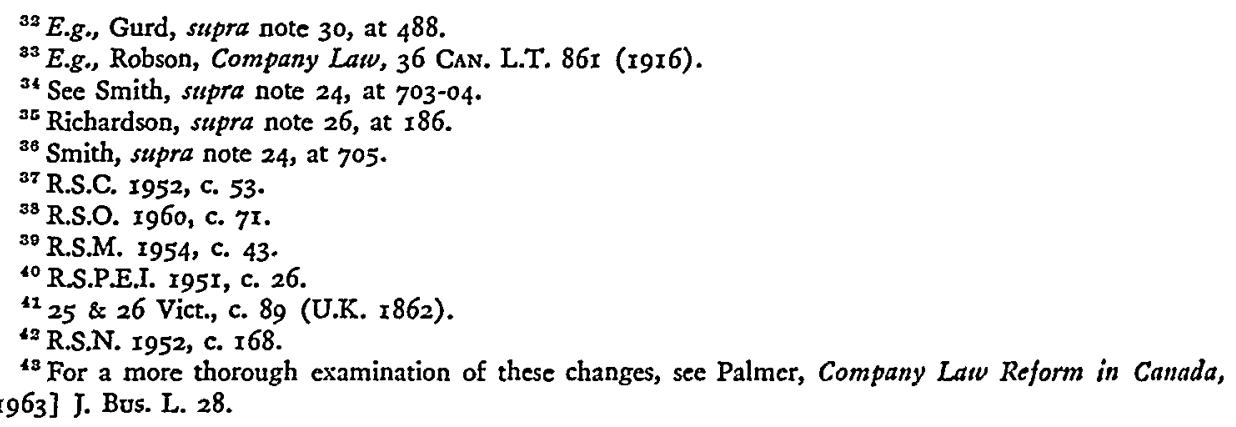


act has not yet been accepted by one legislature and, even with the act in existence, the federal government intends to bring down its own and different act in this field. ${ }^{44}$ It is, therefore, premature to say that anything has been accomplished by this work on uniformity.

The cause of uniformity in Canada has also been hindered by judicial treatment of provisions in the British North America Act relating to treaties. Before r947, only two parts of that act were thought capable of supporting the federal treaty-making power: section 132 and the Dominion's residual power. Whatever doubt there might have been as to the scope of these sections, the letters patent of 1947 , constituting the office of Governor-General of Canada, placed certain questions beyond controversy. Specifically, by authorizing the Governor-General, with the advice of the Canadian Privy Council or any member thereof, to exercise "all powers and authorities lawfully belonging to us in respect of Canada," the federal government has been entrusted with the power to negotiate, sign, and ratify treaties of all types. ${ }^{45}$ Thus, the federal executive can enter into valid and binding ${ }^{46}$ treaties, going then to Parliament for legislation to implement them. In short, the signing of a treaty by the executive does not make its terms law in Canada. This position is similar to that sought to be introduced in the United States by the Bricker amendment. ${ }^{47}$

It is in the area of implementation of treaties that the real problem has arisen. Only section 132 of the British North America Act clearly gives the federal government the power to implement treaties. However, this section only deals with treaties between the British Empire and foreign countries, and it is politically inconceivable that any Canadian government would now let Great Britain carry on its international relations in order to make use of section $\mathrm{I}_{32}$. This provision must, therefore, be considered a dead letter. Up to the thirties, however, it was assumed from the cases ${ }^{48}$

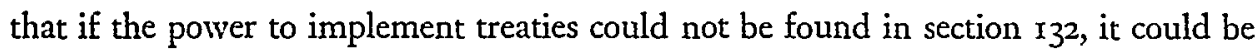
in the residual power. ${ }^{49}$ This confidence was rudely shattered in 1936 by the Labour Conventions case when both the Supreme Court of Canada ${ }^{50}$ and the Judicial Committee of the Privy Council ${ }^{51}$ held that although the power to enter into treaties lay

4This act (at present Bill S-22) passed its third reading in March 1965. Financial Post (Toronto), March 20, 1965, p. 7 .

45 This transmission of prerogative power was not divided in the same way that the power to incorporate was passed on in the Bonanza case, supra note 18 . For an explanation of this, see Northey, Constitutional Limitations as Affecting the Validity of Treaties, II U. Tononro L.J. I75, I83 (I956). The position previous to the grant of these letters patent is shown in MacDonald, Canada's Power to Perform Treaty Obligations, II CAN. B. REv. 581, 664 (I933).

${ }^{10}$ See Lederman, stipra note 8, at 29r-92; Jenks, The Present Status of the Bennett Ratifications of International Labour Conventions, I5 CAN. B. REv. 404, 473-74 (1937).

" Sce Lederman, supra note 8, at 292.

${ }^{18}$ See, e.g., In re the Regulation and Control of Aeronautics, [1932] A.C. 54, [1932] I D.L.R. $5^{8}$ (P.C.); and In re Regulation and Control of Radio Communication in Canada, [1932] A.C. 304, [I932] 2 D.L.R. 8I (P.C.).

${ }^{10}$ See Northey, supra note 45 , at I75-85; and Szablowski, Creation and Implementation of Treaties in Canada, 34 Can. B. Rev. 28 (I956).

50 [1936] S.C.R. $46 \mathrm{r} ;$ [1936] 3 D.L.R. 673.

${ }^{51}$ A.G. C2n. v. A.G. Ont., [1937] A.C. 326 , [1937] I D.L.R. 673 (P.C.). These cases were criticized 
with the federal government, when their subject-matter fell within the heads of power enumerated in section ninety-two, the power to implement them lay with the provinces. As a result, the possibility of entering into international obligations on provincial matters which would become binding on all provinces was remote. Obviously this created great difficulties for a country which was becoming increasingly involved in international trade.

The Labour Conventions case raised problems which still exist in Canada. Thus, there is a possibility that the Supreme Court of Canada might wish to review the whole problem now that it is this country's final court of appeal. When this situation arises there are several courses of action that might be taken. Section 132 could be read to cover novel circumstances, ${ }^{52}$ especially in light of the new grant of letters patent in $1947 ;^{53}$ a second look might be taken at the scope of the residual power; ${ }^{54}$ a compromise position might be taken whereby the federal government would be given the power to implement matters of national importance; ${ }^{\text {t5 }}$ or, indeed, the present position might be maintained. ${ }^{\text {E6 }}$ It is difficult to determine which course will be taken, ${ }^{57}$ but most authorities feel that the effects of the Labour Conventions case will be to some extent ameliorated. ${ }^{58}$ The necessity of such change is clear: Canada is becoming ever more deeply involved in international trade and if she is to participate fully in the developing international trading blocs ${ }^{50}$ it is necessary that the federal government be able to ensure that international commitments will be implemented; for this, international liability is not enough. Constitutional amendment has been suggested as a solution to this problem, ${ }^{60}$ but this would not seem feasible as the provinces are presently seeking more, not less, power. The only satisfactory result can come from the courts.

The remaining area of the constitution which affects the problem under discussion

bitterly in Canada. See the symposium in Is CAN. B. Rev. 393 et seq. (1937); McKenzie, Canada: The Treaty-Making Power, 18 BRIT. YB. INT'L L. I72 (1937); and Starke, The Privy Council and the Competence of Federal Legislatures to Legislate Pursuant to International Obligations, XI Austu. L.J. 45 (1937). One of the more galling aspects of this case was that the deciding vote was cast by Sir Sidney Rowatt, "a 'taxation judge' who ... sat throughout the 1937 hearings in his overcoat making neither note nor comment." See Mackinnon, Labour Conventions Case: Lord Wright's Undisclosed Dissent?, 34 CAN. B. Rev. II4, II7 (I956).

${ }^{62}$ See Scott, The Consequences of the Privy Council Decisions, 15 CAN. B. REv. 485, 487 (1937).

"s Northey, supra note 45 , at $183-85$.

64 See Szablowski, supra note 49 , at 58-59.

t5 See Lederman, supra note 8 , at 292.

${ }^{66}$ See Cronkite, The Social Legislation References, 15 Can. B. Rev. 478, 479 (1937); Kennedy, The Interpretation of the British North America Act, 8 CAMB. L.J. I46, I59 (1942).

${ }^{67}$ See MacDonald, The British North America Act: Past and Future, I5 CAN. B. Rev. 393, 415 (1937).

${ }^{68}$ See Lederman, supra note 8 , at 292. The present position in Canada is also set out in Cheffins, The Negotiation, Ratification and Implementation of Treaties in Canada and Australia, 4 ALTA. L. Rev. 312, 5 Alta. L. Rev. 4 ro (r958-60).

${ }^{50}$ The extent to which this has resulted in supportive federal legislation is noted in the Financial Times (Can.), March 29, 1965, p. 21.

${ }^{\circ 0}$ See R. B. Stewart, Treaty Relations of the British Commonwealth of Nations 300.03 (I939); Matas, Treaty-Making in Canada, 25 CAN. B. REv. 458 (r947). 
is section ninety-four. Realizing that uniformity of laws would pose problems in a federal country, many of the founders of confederation attempted to provide solutions to this in the constitution. At the Quebec Conference, which was called to establish the principles of legislative union, it was agreed that the federal government should have a specific power to provide for uniformity of provincial laws (except those of Quebec) in the equivalent of the present section ninety-one.61 This resolution received such strong support in the provincial legislatures, ${ }^{62}$ that an even greater federal power in this area was adopted by the London Conference of $1866^{63}$ For unexplained reasons, however, the final wording in the innocuous section ninetyfour of the British North America $\mathrm{Act}^{64}$ was weaker than the earlier resolutions. By it the Dominion was only given power to make provision for uniformity of laws relating to property and civil rights in the three common law provinces; ${ }^{65}$ and any federal act designed to do this required adoption by the legislature of the province before it had any operative effect in such province. Only when an act had been thus adopted did the Dominion acquire in perpetuity full legislative power to deal with its subject matter. ${ }^{66}$

This provision, therefore, contributes little to the cause of uniformity: it requires a voluntary surrender of legislative competence by a province-a rather far-fetched possibility in Canada today-and it is far from clear whether it only covers the three named provinces ${ }^{67}$ or all provinces except Quebec. ${ }^{68}$ In any event, it has never been used. In 1869 , the Dominion attempted to move under this section. ${ }^{69} \mathrm{~A}$ Commission was appointed which brought down a favorable report two years later, ${ }^{70}$ but the matter was not mentioned again. ${ }^{71}$ Indeed, except for a speech in the House of Commons in $1912,{ }^{72}$ and an occasional academic outburst, ${ }^{73}$ the section has remained a dead letter to this day and there is little prospect that there will be any change.

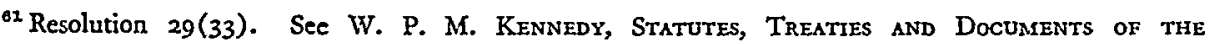
Canadian Constitution 54 I-42 (2d ed. 1930).

${ }^{62}$ See, e.g., Sir John A. Macdonald, later first Prime Minister of Canada: Province of Canada, Parliamentary Debates $4 \mathrm{I}$ (3d Sess. I865).

${ }^{63} \mathrm{KeNNEDY}$, op. cit. supra note $6 \mathrm{I}$, at $6 \mathrm{I}_{3}-\mathrm{I}_{4}$.

o4 See MacTavish, supra note 3 . On this point $\$ 97$, which also deals with uniformity, only complements $\S 94$, and is of little practical importance.

${ }^{O E}$ That is, Nova Scotia, New Brunswick, and Ontario.

${ }^{\circ}$ See 2 Report of the Royal Commission on Dominion-Provincial Relations 73 (1940).

${ }^{67}$ Ibid. Similar views to the effect that $\$ 94$ only covers these three provinces can be found in Russell, Provisions of the British North America Act for Uniformity of Provincial Laws, 34 Can. L.J. (n.s.) 513, 521 (I898); and Note, 46 CAN. L.J. (n.s.) 41 (1910).

${ }^{\circ B}$ This view is taken by Lafleur, Uniformity of Laws in Canada, 35 CAN. L.T. 396 (I915), also found in $5 \mathrm{I}$ CAN. L.J. (n.s.) I88 (I9I5); and, more persuasively, by the doyen of Canadian constitutional lawyers, F. R. Scott: Section 94 of the British North America Act, 20 CaN. B. Rev. 525, 529 et seq. (I942).

${ }^{\circ}$ See Journat. of House of Commons 43, I86, 268 (Canada I869).

${ }^{70}$ See Sessional Papers No. I6 (Canada I87r).

${ }^{71}$ See Scott, supra note 68, for the history of this event.

${ }^{72}$ See MacTavish, supra note 3 , at 39.

${ }^{73}$ See Scott, stupra note 68; and Note, 32 CAN. L.J. 464 (1896).
} 


\section{UNIFORM LEGISLATION}

The division of legislative competence in a federation does not necessarily lead to diversity in the actual laws enacted: common traditions, mutual self-restraint and economic necessity can all prevent this. Although some might cavil at the suggestion, ${ }^{74}$ it would seem clear that none of these factors in Canada has been sufficiently strong to result in satisfactorily uniform legislation. Even in the area of commercial law where these factors would seem to be strongest, ${ }^{75}$ a cursory glance through the statute books of the various provinces gives some idea of the diversity which exists. ${ }^{70}$ Of course, a certain amount of uniformity does occur. For example, Sale of Goods and Partnership acts are substantially uniform outside Quebec, while Legitimation and Reciprocal Enforcement of Maintenance Orders acts have, in substance, been enacted in all provinces. This relatively minor achievement has, in part at least, been attributed to the work of the Conference of Commissioners on Uniformity of Legislation in Canada.

The Uniformity Commissioners first met in Igr8 as a result of pressure from lawyers ${ }^{77}$ and the Canadian Bar Association, one of whose objects was to promote "uniformity of legislation throughout Canada so far as consistent with the preservation of the basic systems of law in the respective provinces...." ${ }^{278}$ Aside from such fatuous goals as creating national pride, ${ }^{79}$ the main objective of the Commissioners was to promote unity of commercial laws, ${ }^{80}$ "without disturbing any fundamental principles in the basic systems of the several provinces of Canada, and without trenching in the least degree on treaty rights and historic traditions." ${ }^{\text {"1 }}$ The results achieved by this body have been disappointing, notwithstanding views indicating that

\footnotetext{
(I958).

${ }_{75}$ In this respect, the existence of a high degree of mutual self-rcstraint and cconomic necessity in this area are obvious, but it is also to be pointed out that there is, according to some scholars, a common origin of law in the custom of merchants. See Falconbridge, The Law Merchant in Canada, 49 CAN. L.J. (n.s.) 637,650 (1913); also F. P. Walton, The ScOpe and INterpretation of the Civil Code of LOWER CANADA 21 (1907).

${ }^{70}$ For examples of this diversity of legislation in the field of corporation law, see Labrie \& Palmer, op. cit. supra note 23, passim. It should be pointed out also that in the vital area of tax law there is not a trace of uniformity and little in the way of agreements to limit double taxation.

${ }^{77}$ See, e.g., Cameron, $A$ Plea for a Uniform Contract of Fire Insurance for Canada, I9 CAN. L.T. yos (1899); Gordon, Uniform Legislation, 20 CAN. L.T. 187 (1900); Henderson, Uniformity in Provincial Laws, ig CaN. L.T. 209 (1899); Popple, Legislative Chaos in Canada, 38 Can. L.T. 628 (19r8); Russell, Provisions of the British North America Act for Uniformity of Provincial Laws, 34 CaN. L.J. (n.s.) 513 ( 1898$)$; and Editorial, 32 Can. L.J. (n.s.) 464 ( 1896$)$.

${ }_{78}$ Proceedings of the Canadian Bar Association I (1915). The development of the strong intercst of this body, which was founded in 1915 , in uniformity of law is explained in Surveyer, L'Association du Barreau Canadien et l'Uniformité des Lois, I Can. B. Rev. 52 (I923). See also Shannon, Uniformity of Legislation, $8 \mathrm{CAN}$. B. Rev. 28 (r930).

79 This was one of the stated objects of the first president of the conference. Sce Aitkins, Canadian Unity and Uniformity of Laws, 52 CAN. L.J. (n.s.) 298 (I916).

${ }^{80}$ See Note, 16 J. Comp. Leg. \& INT'L L. (3d ser.) 147 (1934).

${ }^{81}$ Lafleur, Uniformity of Laws in Canada, 35 Can. L.T. 396, 399 (1915).
}

${ }^{74}$ E.g., Morris, The Problem of Uniform Arbitration Legislation in Canada, 13 ARB. J. (n.s.) x03 
it has achieved its purpose so well that there is now no commercial subject of importance outstanding which requires the attention of the Conference. ${ }^{82}$

The failure of the Commissioners is apparent from a study of the progress reports this body publishes each year indicating the model acts prepared and the jurisdictions which have adopted them completely or in part. ${ }^{83}$ On this face these charts seem to indicate considerable success. For example, some jurisdictions have enacted, at least in part, over thirty of the forty-seven acts prepared by the Commissioners, and similarly, some of their acts have been accepted, again at least in part, in all jurisdictions. Aside from an evaluation of the less than complete acceptance of these model acts, ${ }^{84}$ the following factors detract from this rosy picture: the lack of discrimination in relative importance of the jurisdiction and legislation involved, and the possibility that the real influence for the act's adoption came from a group different than the Uniformity Commissioners. For example, the tables of the Commissioners do not distinguish between the adoption of a model act in the Yukon Territory with a population of about I2,000 and Ontario with over five million. Again, no attempt is made to distinguish between, say, the record of the Cornea Transplant and the Corporations Securities Registration acts. Finally, no indication is given that some of the most successful acts sponsored by the Conference were also receiving support from other bodies. To avoid this, table one deals only with the records of acts relating to commercial matters in the provinces containing at least three per cent of the total Canadian population, rather than statutes on non-contentious matters ${ }^{85}$ in any jurisdiction at all; if the main object of the Commissioners is to achieve uniformity in commercial legislation in Canada, it can hardly bolster its case by the adoption of an act reversing Russell $v$. Russell ${ }^{86}$ in a province with a popula-

${ }^{83}$ See Note, supra note 80.

${ }^{83}$ See, e.g., Conference of Commissioners on Uniformity of Legislation in Canada, Proceedings of the Forty-Sixth ANwull Meeting [hereinafter cited as Proc. UNiformity Comaissioners] 14-15 (I964).

84 In approximately half the cases where a model act has been adopted, it has not been adopted in its totality (I4I in 303 times).

${ }^{86}$ Aside from strictly commercial matters, model acts have been prepared in four other areas: torts, wills and trusts, procedure, and family law. The following is a list of these acts under the above headings with the year of promulgation in brackets:

(i) Torts: Contributory Negligence (1924), Defamation (1944), Fatal Accidents (1964), and Highway Traffic and Vehicles-Rules of the Road (1955);

(ii) Wills and Trusts: Appointment of Beneficiaries (1957), Devolution of Real Property (1927), Intestate Succession (1925), Perpetuities (1954), Survivorship (I939), Testators Family Maintenance (1945), Trustee Investments (I957), Variation of Trusts (196r), and Wills (I929);

(iii) Family Law: Domicile (r96I), Legitimation (1920), Russell v. Russell (1945), and Married Women's Property (I943);

(iv) Procedure: Affidavits before Officers (1953), Evidence (194I), Foreign Affidavits (1938), Foreign Judgments Recognition (1933), Judicial Notice of Statutes and Proof of State Documents (I930), Limitation of Actions (1920), Photographic Records (1944), Presumption of Death (I960), Proceedings Against the Crown (1950), Reciprocal Enforcement of Judgments (I924), Reciprocal Enforcement of Maintenance Orders (1946), Service of Process by Mail (1945), Survival of Actions (1963), and Survivorship (1939); and

(v) Miscellaneous Topics: Conflict of Laws (I953), Cornea Transplant (1959), Interpretation (I938), Landlord and Tenant (1937), Regulations (I943), and Vital Statistics (I949).

86 [1924] A.C. 687 (H.L.). 
TABLE I

Adoption of Model Acts Relating to Commercial Matters

\begin{tabular}{|c|c|c|c|c|c|c|c|c|c|c|}
\hline \multirow[b]{2}{*}{$\begin{array}{l}\text { NAME OF ACT } \\
\text { (Year Prepared) }\end{array}$} & \multicolumn{7}{|c|}{ JURISDICTIONS (a) } & \multicolumn{3}{|c|}{ Totals } \\
\hline & 范命 & 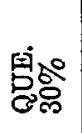 & $\dot{0} \dot{0}$ & 岁通 & 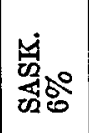 & 悹品 & $\begin{array}{l}\dot{2} \\
\dot{z}\end{array}$ & $\dot{m}$ & 㸃 & 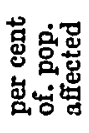 \\
\hline $\begin{array}{r}\text { Conditional Sales } \\
(1922)\end{array}$ & & & (d) & & & & $C(b)$ & C & 2 & $7 \%$ \\
\hline $\begin{array}{l}\text { Partnerships Registration } \\
\text { (1938) }\end{array}$ & & & & & $\mathrm{M}(\mathrm{b})$ & & & $M$ & 2 & $7 \%$ \\
\hline $\begin{array}{l}\text { Bills of Sale } \\
\text { (1928) }\end{array}$ & & & & C & C & M & $\mathbf{C}$ & M & 5 & $25 \%$ \\
\hline $\begin{array}{l}\text { Bulk Sales } \\
\text { (1920) }\end{array}$ & & & C & $\mathbf{C}$ & & $\mathbf{M}$ & $\mathbf{M}$ & $\mathbf{C}$ & 5 & $28 \%$ \\
\hline $\begin{array}{l}\text { Corporation Securities } \\
\text { Regulation (1931) (c) }\end{array}$ & C & & & & $\mathbf{C}$ & & $\mathbf{C}$ & & 3 & $44 \%$ \\
\hline $\begin{array}{l}\text { Frustrated Contracts } \\
\qquad(1948)\end{array}$ & C & & & $\mathbf{C}$ & & $\mathbf{C}$ & & $\mathbf{C}$ & 4 & $40 \%$ \\
\hline $\begin{array}{l}\text { Assignment of Book Debts } \\
\text { (1928) }\end{array}$ & $\mathrm{C}$ & & & $M$ & $\mathbf{C}$ & $M$ & C & $\mathbf{M}$ & 6 & $57 \%$ \\
\hline $\begin{array}{c}\text { Warehouse Receipts } \\
\text { (1945) }\end{array}$ & $M$ & & $\mathbf{M}$ & $\mathrm{C}$ & & $\mathbf{M}$ & $\mathbf{C}$ & $\mathrm{C}$ & 6 & $62 \%$ \\
\hline $\begin{array}{c}\text { Warehouseman's Lien } \\
(1921)\end{array}$ & $\mathrm{C}$ & & C & $\mathrm{C}$ & C & $\mathrm{C}$ & C & $\mathbf{C}$ & 7 & $68 \%$ \\
\hline Totals & 5 & 0 & 3 & 6 & 5 & 6 & 7 & 8 & 40 & - \\
\hline
\end{tabular}

Drimen

II. Also Supported by the Association of Superintendents of Insurance

\begin{tabular}{l|l|l|l|l|l|l|l|l|l|l}
\hline Life Insurance & $\mathrm{C}$ & & & $\mathrm{C}$ & $\mathrm{C}$ & $\mathrm{C}$ & $\mathrm{C}$ & $\mathrm{C}$ & 6 & $50 \%$ \\
\hline Fire Insurance & $\mathrm{C}$ & & $\mathrm{M}$ & $\mathrm{C}$ & $\mathrm{C}$ & $\mathrm{C}$ & $\mathrm{C}$ & $\mathrm{C}$ & 7 & $68 \%$ \\
\hline
\end{tabular}

III. Acts Substantially Following the Imperial Conference Acts

\begin{tabular}{l|l|l|l|l|l|l|l|l|l|l}
\hline Partnership & $\mathrm{C}$ & & $\mathrm{C}$ & $\mathrm{C}$ & $\mathrm{C}$ & $\mathrm{C}$ & $\mathrm{C}$ & $\mathrm{C}$ & 7 & $68 \%$ \\
\hline Sale of Goods & $\mathrm{C}$ & & $\mathrm{C}$ & $\mathrm{C}$ & $\mathrm{C}$ & $\mathrm{C}$ & $\mathrm{C}$ & $\mathrm{C}$ & 7 & $68 \%$ \\
\hline
\end{tabular}

(a). These are listed, from left to right, in order of the size of population. The percentage the provinces population bears to tho wholo country is in brackets beside its name. ONT. is Ontario; QUE., Quebec; B.C., British Columbia; ALTA., Alberta; BASK., Saskatchewan; MAN., Manitoba; N.S., Nova Scotia; and N.B., New Brunswick.

(b) $C$ indicates an act has been adopted in its entirety; $M$ that it has been enacted in a modified form.

(c). No similar statute has been enacted by the Dominion in relation to its porer to incorporate, thus further limiting tho effect of tho Model Act.

(d). B.C. adopted and later repealed the Model Conditional Sales Act.

tion of roo,000. ${ }^{87}$ Similarly, statutes which have been also supported by other bodies are so indicated.

A cursory examination of table one indicates the lack of success achieved by the Uniformity Commissioners. In no case have they been successful in having their

${ }^{8 \tau}$ Stats. P.E.I. I946, c. II, $\$ 2$ (now in the Evidence Act, R.S.P.E.I. I95I, C. $52 \S 5$ ). 
commercial acts adopted in all important jurisdictions and, to the extent that they have succeeded, the acceptance of an act seems to be in inverse proportion to its importance. Gauging their progress by the percentage of population affected by the acts, the picture becomes even more discouraging. ${ }^{88}$ Again, perhaps as a result of a comparative paucity of legislative draftsmen, there seems to be a tendency for their acts to be adopted only in the smaller provinces. Thus, although the Model Bills of Sale Act has been adopted in five provinces, only twenty-five per cent of the population of Canada is affected by it, making both the Ontario and Quebec acts more important. Using monetary tests, the results are equally unsatisfactory. For example, in the case of the Model Conditional Sales Act which has been adopted in six of the eleven provinces, the balance outstanding on retail paper purchased in 1956 was ninety-eight million dollars in the "uniform" provinces and eight hundred and fiftytwo million dollars in the others, with only about ten per cent of Canadians affected by the Model Act. ${ }^{89}$ In short, the Commissioners clearly have failed to achieve anything like uniformity in the areas of commercial law with which they have chosen to deal.

The failure of the Commissioners is shown further by the adoption of uniform acts in Fire and Life Insurance, and the Partnership and Sale of Goods acts. The first two of these have been accepted completely outside of Quebec and British Columbia. Although the Uniformity Commissioners played a part in their formulation, it was really the Association of Superintendents of Insurance which pressed for their adoption-and in this case with remarkable success. ${ }^{90}$ Again, outside of Quebec, uniformity of legislation has been achieved in partnership and sale of goods legislation as a result of the old Imperial Conferences on these subjects. Thus, one is driven to the conclusion that conferences pushing uniformity can in some cases ${ }^{91}$

${ }^{88}$ Of the total population of $16,000,000$ people in Canada in 1956 , the following list shows the provinces' total population to the nearest 1,000 and the approximate percentage this is of the nation's total:

$\begin{array}{lrlr}\text { Ontario } & 5,405,000(34 \%) & \text { Nova Scotia } & 695,000(4 \%) \\ \text { Quebec } & 4,628,000(30 \%) & \text { New Brunswick } & 555,000(3 \%) \\ \text { British Columbia } & 1,398,000(9 \%) & \text { Newfoundland } & 400,000(2 \%) \\ \text { Alberta } & 1,123,000(7 \%) & \text { Prince Edward Island } & 99,000(-) \\ \text { Saskatchewan } & 881,000(6 \%) & \text { North West Territory } & 19,000(-) \\ \text { Manitoba } & 850,000(5 \%) & \text { Yukon Territory } & 12,000(-)\end{array}$

This listing shows the major failure of the Commissioners in being unable to bring Quebec into the uniformity movement and the obvious uselessness of using the last few jurisdictions as guides to the success of the Commissioners.

${ }^{30}$ See Ziegel, Uniformity of Legislation in Canada: The Conditional Sales Experience, 39 CaN. B. REv. 165 , I8I (196I), for the source of these figures. At that time there were seven "uniform" provinces (Nfd., P.E.I, N.S., N.B., B.C., Yukon and N.W.T.) and four "non-uniform" provinces (Alta., Man., Ont., and Que.) but since then British Columbia, the largest of the former group, has repealed its Model Act.

${ }^{\circ 0}$ The influence of this group is noted in Willis, Securing Uniformity of Law in a Federal SystemCanada, 5 U. Toronto L.J. 352,365 (I944).

02 Thus, although the Imperial Conferences and the Superintendents of Insurance have been successful, other groups besides the Uniformity Commissioners have failed. For example, see the smashing failure of the Canadian-American Commercial Arbitration Commission noted in Domke \& Kellor, Western Hemisphere Systems of Commercial Arbitration, 6 U. Toronro L.J. 307, 325-28 (x946). 
achieve a high degree of success. Therefore, an examination of the reasons for the failure of the Uniformity Commissioners is appropriate.

The most obvious failure of the Commissioners is their lack of success in Canada's second heaviest populated province, Quebec. Thus, approximately one-third of Canadians and a great deal of the country's commerce have been unaffected by efforts towards unity ${ }^{92}$ in spite of the fact that Quebec's Civil Code in commercial matters is founded on the same basis as the common law, in the custom of merchants. ${ }^{93}$ The reason becomes apparent when one looks at the history of the French Canadians' attempts to maintain cultural autonomy and their seeming present desire to achieve even greater political independence. Originally, it was hoped that the work of the Uniformity Commissioners would counteract the above tendencies of the French in Canada. ${ }^{94}$ However, as noted above, when this group was founded it hoped to achieve its goal of uniformity of commercial law "without trenching in the least degree on treaty rights and historic traditions." assurance was not enough to allay the fear of French Canadians that this body would be the spearhead of an Anglo-Saxon cultural invasion, ${ }^{96}$ and it was not until 1942 that Quebec was officially represented at meetings of the Commissioners. ${ }^{07}$ It is also interesting to note than in 1949 the first French Canadian president of the Conference, M. Antoine Rivard, K.C., took the occasion of his inaugural address to state that the position of Quebec at the conference was to maintain the "entire integrity" of the Civil Code, as this was "not only essential to our own existence as a race, but also to the complete unity of the Canadian Nation." $\mathrm{M}$. Rivard seems to be correctly expressing the traditional and still unrevised opinion of Quebec. Therefore, no uniformity seems possible in this area.

In light of the feeling in Quebec, one may excuse the failure of the Commissioners here, as no one else has done better. However, their record in the purely common law provinces is not as impressive as that of other groups, and so a further examination of the operations of this body is indicated.99 An initial criticism of the Com-

${ }^{22}$ Compare also the effect of failure of Quebec to enter into uniform legislation in the area of commercial arbitration noted in Morris, supra note 74, at 105.

${ }^{\text {os }}$ See Falconbridge, supra note 75.

פ4 The use of uniform legislation to pull Quebec out of its isolation was noted early in the efforts to unify Canadian law. See Codification on the Imperial Plan, 32 CaN. L.J. (n.s.) 497, 498 (1896).

${ }^{25}$ See supra note 78 .

${ }^{\circ \theta}$ This point is discussed in Shannon, Uniformity of Laws in Canada, 7 Can. B. Rev. 534 (I929). One only has to read some of the more imperialist-tinged expositions on uniformity of laws to sympathize with the French Canadians' fears. See, e.g., Henderson, Uniformity in Provincial Laws, I9 CaN. L.T. 209 (1899).

${ }^{\circ 7}$ See Note, 5 U. Toronto L.J. I6I (I943).

${ }^{28}$ Proc. Commissioners Uniformity, Appendix O, at I26-27 (1949).

${ }^{\circ 0}$ In this respect I have drawn heavily on the excellent work of Professor Jacob Ziegel of the Faculty of Law, University of Saskatchewan, who has been a pioneer in this field of work. See, for his major articles, Ziegel, supra note 89; and Retail Instalment Sales Legislation: A Historical and Comparative Study, 14 U. Tononto L.J. I43 (I962). The only other article of note which evaluates the work of the Commissioners is Harris, Canadian Reactions to the Uniform Commercial Code, II AM. J. Comp. L. 302 (1962). 
missioners has been that they have limited their efforts to formulating legislation of a non-controversial nature. ${ }^{100}$ Aside from this, the Commissioners' methods of dealing with problems would seem to be so ill-suited to attain general acceptance that their efforts have been largely irrelevant. In a simplified sense, the Commissioners, who meet annually for the five days preceding the meeting of the Canadian Bar Association, usually decide upon a topic to be unified, assign it one of the provincial bodies, and then consider the resulting report at the next annual meeting with a view to its approval. ${ }^{101}$ For several reasons this practice rarely results in adequate results. One such reason is that the personnel engaged in these surveys are usually lacking in expertise in the matters with which they are dealing, ${ }^{102}$ for in Canada, as opposed to its United States counterpart, the members of the Conference are usually deputy attorneys general, legislative counsels, eminent practitioners, and, in only a few cases, law professors. Except occasionally in the case of the latter group, ${ }^{103}$ these men will not have particular detailed knowledge in the fields under examination. Therefore, their reports-and they must be their reports as the Conference is financially impoverished $^{104}$ - are generally composites of existing legislation from other jurisdictions, with no detailed study of the need for change. It is understandable that, except in the case of harassed legislative draftsmen looking for help, these acts are not generally acceptable.

${ }^{100}$ See Willis, supra note 90, at 365 . Compare, however, the views of a Commissioner that "the Conference has ... prepared model legislation of an avowedly creative and reforming character. . .." Read, The Public Responsibilities of the Academic Law Teacher in Canada, 39 CaN. B. REv. 232, 236 (196r). [This article is also reproduced in $14 \mathrm{~J}$. LeGal Ed. 79 (196I).]

${ }^{101}$ Read, supra note I00, at 238, states that the "Preparation of a model Act proceeds through several stages: (a) research by designated commissioners who report to a meeting of the Conference on the desirable features and deficiencies of existing law in Canada and elsewhere and recommend in a general way the type of legislation that they believe is desirable, making special mention of the features to be included and those to be excluded; (b) discussion of the report in principle at a meeting of the Conference and decision whether or not a draft is to be prepared; (c) if it is, the designation of the commissioners of one province to prepare it, and the Conference, with them present, then proceeding to discuss the report in detail and decide the various principles to be adopted; (d) preparation of a draft Act; (e) critical discussion of the principles embodied in the draft Act at a meeting of the Conference resulting in either a reference for further research or a delegation to two or three experienced draftsmen of the task of preparing a semi-final draft; $(\mathrm{g})$ discussion of the semi-final draft as to principles at the Conference and its tentative approval; $(h)$ publication of the tentatively approved draft in the Proceedings, and submission to the Attorneys General, the Canadian Bar Association, and other persons or bodies interested, inviting criticisms and suggestions; (i) consideration by the Conference of any criticisms and suggestions; (j) giving final approval and publication of approved model Act in the proceedings; (k) recommendation of the model Act to the Attorneys General.

102 See Harris, supra note 99, at 302.

${ }^{103}$ In its entire history, only eight academic law teachers have been members of the Conference. They have, however, made a substantial contribution to its work, carrying the major proportion of the research. See Read, supra note I00, at 237. It should be also noted that research among academics in Canada on commercial law topics is notoriously poor. 'Thus, the academics' contribution to the Conference has been on the level of general research ability rather than expertise in any particular field. See Harris, supra note 99 , at 302 , for an examination of this point.

${ }^{10}$ Until the end of World War II each province was required to pay fifty dollars towards the costs of this body, a sum not always paid. See Mac'Tavish, supra note 3 , at 48 . The Commissioners serve with no remuneration. The present donation by each province is $\$ 200$, except in the case of P.E.I. which pays $\$ 100$. Thus, in 1964 the amount available to the Conference was $\$ 2,200$. See supra note 98 , Appendix B. 
The Conference also suffers from attempting to do too much and revising what has been done too often. ${ }^{105}$ For example, in the case of the Model Conditional Sales Act which was introduced in 1922, there were six amendments and two complete revisions between then and $1959 .^{100}$ This deluge of material, all of which must be considered by the Committee of the Whole at the annual meeting, can necessarily have only cursory examination. Then, because this body suffers from the twin defect that membership does not entail acceptance of its work ${ }^{107}$ and the Conference has no formal means of pressuring governments, ${ }^{108}$ the results are left in the limbo of neglected reports of the Conference. The lack of affirmative results should come as no surprise, nor should one expect much change. ${ }^{109}$

Indeed, except for the occasional work of pressure groups such as the Superintendents of Insurance, Canada owes the partial uniformity in the creation of legislation to the laziness of legislative draftsmen and the general influence of English attitudes on the law. Thus, although in an area of law there may not be uniformity throughout Canada, there may be regional uniformity. For example, in the case of Companies Act, there is a high degree of uniformity in the West and between the Federal Act and those of various eastern provinces. ${ }^{110}$ Again, in many areas existing differences tend to be in detail and not in principle. Thus, we find in the area of procedure virtual unanimity of principle, even in Quebec with its civil law background. $^{111}$ Only occasionally do Canadian legislatures innovate, and then usually on the American pattern. There are, however, the differences in detail which remain; the impact of these on commercial life is often softened by the court structure in Canada.

\section{III}

\section{The Canadian Judiciary}

The principal cause of such uniformity as does exist in Canada would seem to derive from the administration of law. By virtue of provisions of the British North

${ }^{105}$ Or, as stated by Ziegel, stipra note 89 , at 183 : "The Conference is too prolific; too hesitant in firmly abiding by a policy when once reached; and too slow, and sometimes too late, in adopting necessary amendments."

${ }^{100} \mathrm{Id}$. at $\mathrm{I8} 3$.

${ }^{107}$ This is, in some quarters, regarded as the basic defect of the Conference, although it is hard to visualize any practical way around this objection. See Willis, stupra note 90 , at 364 .

${ }^{108}$ For further discussion of this point, see Ziegel, stupra note 89, at 200; and Harris, supra note 99, at 312.

${ }^{100}$ For views on this point, compare the pessimistic vicw of Willis, supra note 90, at 364 , with that of Harris, supra note 99 , at $3 \mathrm{I}_{4}$.

${ }^{110}$ Thus, the Companies Acts of the three most westerly provinces, Saskatchewan, Alberta, and British Columbia are virtually the same. See R.S.S. 1953, c. 124; R.S.A. 1955, c. 53; and R.S.B.C. 1960, c. 67. Also the Acts of Manitoba, Quebec, and New Brunswick are very similar to that of the Dominion. See R.S.M. I954, c. 43; R.S.Q. I94I, c. 276; R.S.N.B. I952, c. 33; and R.S.C. 1952, c. 53.

111 Thus, in the present Code of Civil Procedure one sees all the familiar landmarks of English pro. cedure-commencement of action by writ of summons, pleading by way of a concise statement of the material facts, oral discovery, trial by jury in commercial and tort matters, trial in open court and adversary proof, injunctive relief and the extraordinary remedies. See Kilgour, Procedure and ladicial Administration in Canada, in Canadian Jurisprudence: The Crvil Law and Common Law in Canada [hercinafter cited as Canadian JURISpRddencE] 30r (McWhinney ed. 1958). 
America Act both the provinces ${ }^{112}$ and federal government ${ }^{113}$ have been given the power to create their own courts, the latter also being empowered to create a final court of appeal for the provinces. ${ }^{114}$ In practice, however, this has not resulted in federal courts for federal matters and provincial courts for provincial matters. What has occurred has been the superimposition of the Supreme Court of Canada, a federal court, as the final court of appeal, replacing those courts of last resort which existed in the provinces at the time of Confederation. ${ }^{115}$ This court has an extremely wide appellate jurisdiction, so that any case involving more than two thousand dollars can go to $\mathrm{it}^{116}$-a completely different approach from that adopted in the United States, where the Supreme Court will only hear cases of national importance. The only other major federal court, the Exchequer Court, is one of original jurisdiction, and deals with limited matters over which the Dominion has jurisdiction. ${ }^{117}$ Until I949, the Judicial Committee of the Privy Council stood as the final tribunal for all Canadian cases, whether from provincial courts or the Supreme Court of Canada. ${ }^{118}$ This channeling of appeals in all cases to one final court of appeal has had a profound effect on the potential diversity of law in Canada.

Except for Quebec, the common law of each of the provinces has been developed by Canadian courts on the basis of developments in England. In part, of course, this is attributable to the fact that at one time each of the common law provinces "received" the common law of England as a result of statute or English constitutional law. ${ }^{110}$ This acceptance has been wholehearted ${ }^{120}$ and only in the cases where there would be no parallel in English law has recourse been had to American decisions, even though, in commercial cases, the latter would seem more appropriate. ${ }^{121}$

112 Sec. $92(14)$.

$123 \mathrm{Sec}$. IOI.

11* Ibid.

${ }^{116}$ In each province there is a superior court of general jurisdiction from which appeals are taken to the provincial court of appeal. In most cases these are both branches of the province's Supreme Court, the former being called the Supreme Court, the High Court of Justice or the Court of Queen's Bench, and the latter the Court of Appeal or the Appellate Division of the Supreme Court. Below this there are various levels of minor courts, the chief ones being the County and District Courts which try civil and criminal actions and accept appeals from certain inferior courts within their territory. Below this exist a plethora of minor courts such as surrogate, division, magistrate's, and family and juvenile courts.

${ }^{210} \mathrm{Sec}$, on the question of the jurisdiction of this court, the Supreme Court Act, R.S.C. I952, c. 259, $\$ \$ 35-44$. In cases where the sum involved is less than $\$ 2,000$, no appeal is possible without leave of the provincial or the Supreme Court, and this will only be given where the case "involves a matter of public interest or some important question of law or the construction of Imperial or Dominion statutes or a conflict of provincial and Dominion authority on questions of law applicable to the whole Dominion." Per McPhillips, J. A., in Doane v. Thomas, [1922] 3 West. Weekly R. III7, III8 (B.C.C.A.).

${ }^{117}$ The Exchequer Court, which was established in $\Upsilon 875$, is a court of original, but not general jurisdiction, dealing with patent and trade marks, admiralty and tax cases, suits against the Crown and certain other lesser federal matters. See the Exchequer Court Act, R.S.C. I952, c. 98, and L. A. Audetre, The Practice of the Exchequer Court of Canada (2d ed. igo9), for a wider discussion of this body.

${ }^{118}$ See supra note 6.

110 This point is discussed in Lederman, The Common Law System in Canada, in Canadan JunusPRUDENCE 35 et seq.

120 Thus the feudal rules of property were accepted into, and to a great extent still remain part of Canadian law.

${ }^{121}$ E.g., adverse possession of wild lands: Hamilton v. R., 54 S.C.R. 33I, 35 D.L.R. 226 (I9I7); 
Appellate judicial structure in Canada has maintained, to a large extent, the integrity of English common law as "the common law of Canada." This stems from the fact that the Supreme Court of Canada regards it as its function "not to aid the litigant, or to correct the errors of provincial courts, but to secure uniformity in matters that concern the whole of Canada." 122 Thus, although there may be differences as to the common law at the provincial level, these differences only represent the particular province's "view" of the law. The correctness of these "views" is subject to the decision of the Supreme Court of Canada and, until this latter court so decides, any differences are regarded as pathological. In short, Canada has rejected what is known in the United States as the rule of Erie Railroad v. Tompkins, ${ }^{123}$ and has one common law, that of England.

The rules of stare decisis adopted by Canadian courts have reinforced unifying trends in the common law, with English common law as the ideal. Thus, it was clear law until 1949, when appeals to the Privy Council were abolished, that every provincial court was bound by decision of the House of Lords, ${ }^{124}$ the Privy Council, ${ }^{125}$ decisions of the Supreme Court of Canada not inconsistent with these two bodies, ${ }^{120}$ and any decision of that province's court of appeal. ${ }^{127}$ All other decisions-whether those of sister provinces or the English court of appeal ${ }^{128}$-were merely persuasive, not binding. Thus, the decisions of English courts have been decisive in theory and practice. As a result, the unity of the English common law was imported to Canada along with the intellectual attitudes of that country.

The abolition of appeals to the Privy Council in 1949 has opened up possibilities for Canada to wean itself away from the often inappropriate English jurisprudence, while still retaining and creating a unified, though repatriated, common law in the Supreme Court of Canada. The psychological weight of the Privy Council, however, has weighed heavily on Canadian judges and little real independence has been shown. ${ }^{129}$ The strict doctrine of state decisis has been re-affirmed by the Court, ${ }^{130}$

problems resulting from timber drives: Roy v. Fraser, 36 N.B.R. I13 (C.A.). However, attempts to use American precedents in corporation law meet with little success. See the attempt to introduce the concept of pre-emptive rights in Stokes v. Continental Trust Co., 186 N.Y. 285,78 N.E. I090 (C.A. 1906) into Canada: Martin v. Gibson, 15 O.L.R. 623, ro O.W.R. 66 (S.C. 1907); Harris v. Sumner, 39 N.B.R. 204 (C.A. r909); and Bonisteel v. Collis Leather Co., 45 O.L.R. 195, 15 O.W.N. 465 (S.C. 1919).

182 Willis, supra note 89 , at 356 .

${ }^{182} 304$ U.S. 64 (1938). On this point, see Read, Some Characteristics of the Judicial Process in Common Law Canada, 1906-1956, in The Administration of Justice in Retrospect 58 (Harding ed. 1957).

${ }_{124}$ Robins v. National Trust Co., [I927] A.C. 5I5, [I927] 2 D.L.R. 97 (J.C.).

${ }^{125}$ See Williams, Stare Decisis, 4 Can. B. Rev. 289, 297 (r926). Cf. Negro v. Pietro's Bread Co., [I933] O.R. Ir2, [x933] I D.L.R. 490 (C.A.).

${ }_{126}$ Stuart v. Bank of Montreal, 4I S.C.R. 5 I6, 548 (1909).

127 Woods Mfg. Co. v. The King, [I95I] S.C.R. 504, [195I] 2 D.L.R. 465.

${ }^{128}$ But contrast the Robins case, supra note 124, with Trimble v. Hill, 5 App. Cas. 342 (J.C., 1879).

${ }^{120}$ This problem was anticipated long before this change took place. See W. P. M. KENNEDY, THE Constitution of CANADA 550-51 (2d ed. 1938). An appraisal of the Supreme Court of Canada's work since 1949 can be found in V. C. MacDonald, Legislative Power and the Supreme Count in tiIe FifTiEs (I96I).

${ }^{180}$ Woods Mfg. Co. v. The King, supra note 127 . As yet the court has not grappled with the 
and English cases are almost as decisive as ever. Change will come, however, as the older generation of lawyers, awed by hearings before the Privy Council and largely educated by the profession in bar association-dominated non-university law schools, dies out. The new generation of lawyers is being trained in University law schools by professors who have usually done graduate work in the United States. ${ }^{131}$ These men find the positivist philosophy of English law alien to their way of thinking; the American legal realists' approach is much more congenial. As their inAluence increases, the English tradition in the courts should diminish.

Even when English influence wanes, the Canadian court system will still tend to promote unity. All that will be different is that the Supreme Court of Canada will become the intellectual style-leader in the hierarchy of Canadian courts. So also will remain the many canons of statutory interpretation which tend to unify in areas outside of common law. For example, in the case of the interpretation of federal legislation in provincial courts, decisive weight is given to the interpretation placed on it by the courts of a sister province for "the law is in fact the same in all the Provinces and ... it is unseemly for the Courts to declare that it is not so, where there is a higher Court that can correct any error with propriety and Parliament is equally able to do so."132 Also when one province adopts the statutes of sister provinces it also accepts the interpretation of the courts of that province as it stood at that time, ${ }^{133}$ but not later decisions of those courts ${ }^{134}$ or of the legislature involved. ${ }^{135}$ In short, the administration of law in Canada is particularly conducive to uniformity, and the loss of English influence should not detract from this. ${ }^{\mathbf{1 3 6}}$

In only one major area have the courts applied the common law in such a way as to create disunity. This is the conflict of laws. Basically, the difficulty has been caused by a refusal of the courts to discriminate between the application of this branch of the law in cases involving international and inter-provincial factors. Lacking a "full faith and credit" clause in the British North America Act, ${ }^{137}$ each province

problem of whether, as successor to the Privy Council as the final court of appeal for Canada, it has succeeded to that body's ability, as a formal matter, to change its own decisions. On this point see Rand J., in Reference Re Farm Products Marketing Act, [1957] S.C.R. 98, 212-13, 7 D.L.R.2d 257, 27I-72 (1957). See also Friedmann, Stare Decisis at Common Law and Under the Civil Code of Quebec, 3I CAN. B. REv. 723, 749 (1953). It should be noted, however, that stare decisis is only an acceptable doctrine as long as there is the possibility of constitutional amendment. If present attempts to limit amendments of the B.N.A. Act are successful, therefore, the court may be obliged to reconsider its position. See generally McWhinney, Amendment of the Constitution, in Studies in Federalism 790 (Powie \& Friedrich ed. I954).

${ }^{131}$ The effects of professional control over legal education in Canada is noted in Wright, Should the Profession Control Legal Education?, 3 J. Legar Ep. I (I950).

${ }^{182}$ Re Peters, [1937] 2 D.L.R. 786, 787, [1937] I West. Weekly R. 787, 788 (Alta., S.C.).

133 Ward v. Serrell, 3 Alta. L.R. I38 (S.C., Igro).

184 McMillan v. Pierce, I3 Alta. L.R. I5I, 37 D.L.R. 242 (Alta., C.A. I9I7),

${ }^{105}$ Deugau v. Morrison, [1938] 4 D.L.R. 353, [1938] 2 West. Weekly R. 297 (Alta., C.A.).

${ }^{136}$ It should be noted here that the Privy Council heard very few Canadian cases in any one year, twelve being about the maximum. Thus, the abolition of appeals to this body can have little effect on the administration of justice, except in a psychological sense. See Cronkite, The Judicial Committee of the Privy Council, I SASK. B. Rev. I4 (1936).

${ }^{137}$ On this point, see Castel, Conflict of Laws-Some Differences Between the Systems Found in the United States and Canada, II AM. J. CoMp. LAw 315, 315-I7 (1962). 
thus becomes a "foreign country" when elements of its law are introduced into cases in a sister province. ${ }^{138}$ The result of this view in a country with a high degree of economic and social interaction has been chaos: ${ }^{139}$ proof of the law of another province in a country whose laws and social attitudes are so similar, except in the case of Quebec, is ridiculous, and the problems of recognition of foreign judgments in a peripatetic society unbearable. As Professor Willis has stated, 140 "where business and pleasure do not take account of provincial boundaries, the result is confusion and unreality."

It should also be noted that the composition of the Supreme Court of Canada has a strong unifying effect on law. At present, there are nine members of this court, one-third of which are from Quebec to ensure that there are Civilians on the court. ${ }^{141}$ This body is a "mixed" court, dealing with all matters whether public or private in nature. ${ }^{142}$ Thus, its members tend not to be specialists in law, but rather former leading counsel chosen for wide experience in legal matters. ${ }^{143}$ As such, for the reasons pointed out earlier, these men, outside of those from Quebec, tend to be strongly influenced by English attitudes. ${ }^{144}$ The refusal of this court to accept the Brandeis Brief ${ }^{145}$ and its contempt of foreign cases $^{\mathbf{1 4 6}}$ well evidences this. As the court sits en banc these views predominate in the court, and can easily sweep aside opposition from the Quebec judges. ${ }^{147}$

These factors have resulted in the introduction of common law concepts into the civil law and thus tended to reduce the potential for diversity there. In short, the Civil Code has been treated, as has the British North America Act, as an ordinary statute of "a Legislature established with the British Empire." Alts Although probably

${ }^{138}$ See A.-G. for Alta. v. Cook, [rg26] A.C. 444, [1926] 2 D.L.R. 762 (P.C.); and Trotticr v. Rajotte, [r940] S.C.R. 203, [1940] I D.L.R. 433 .

${ }^{180}$ For a broader discussion of this problem, see Palmer, Torts in the Inter-Provincial Conflict of Latus, I7 FAc. Rev. I (1959) passim. This chaos has been particularly prevalent in commercial cascs where the effect of much legislation of "foreign" provinces has been wiped out by classifying it as procedural rather than substantive. See Canadian Acceptance Corp. v. Matte, 9 D.L.R.2d 304, 22 West. Weekly R. (n.s.) 97 (Sask., C.A. 1957).

140 Willis, supra note 90 , at 366 .

${ }^{141}$ See the Supreme Court Act, R.S.C. 1952, c. $259, \S \S 4,6$.

${ }_{1 \$ 2}$ Thus, the Supreme Court of Canada does not have a division of "public" and "private" functions as in France with the Conseil d'Etat and the Cour de Cassation, nor is it a purely "public" tribunal as is the Supreme Court of the United States. See von Mehren, The Judicial Process: A Comparative Analysis, 5 AM. J. Comp. Law I97 (1956).

${ }^{148}$ For a fuller discussion of how judicial appointments are made in Canada, see Clark, Appointments to the Bench, 30 CAN. B. REv. 28 (1952).

144 A former Chief Justice of the Supreme Court of Canada once remarked that it was his "greatest wish to anticipate the thoughts of the Judicial Committee."

${ }^{145}$ See Kerwin J., in Saumur v. Quebec, [1953] 2 S.C.R. 299, 324, [1953] 4 D.L.R. 641, 666.

${ }^{140}$ See the Saumur case, supra, passim. Compare, however, Kerwin, Constitutionalism in Canada, in GOVERNMENT UNDER LAw 453 (Sutherland ed. 1956).

${ }^{147}$ For example, Taillon v. Donaldson [I953] 2 S.C.R. 257 , the common law majority voted against the civilian minority and decided that the common law principle of the true welfare of the child in custody eases must prevail over principles recognized in the Civil Code. See Lalande, Comment, 33 Can. B. Rev. 950 (1955).

${ }^{148}$ Per Lord Sumner in Quebec Railway, Light, Heat and Power Co. v. Vendry, [I920] A.C. 662, 67 , 52 D.L.R. I36, I38 (P.C.). 
unintentionally,--for one wonders how acquainted the judges are with the writings of leading (metropolitan) French jurists-the whole jurisprudence of the French Civil Code has been disregarded. Thus, for example, in the best tradition of the English courts travaux préparatoires have not been used. ${ }^{149}$ In result, common law concepts have been insinuated into the Code at the expense of French-Canadian hostility as shown by Quebec demands to have cases based on the Quebec Civil Code heard only by the Civilians on the Supreme Court. ${ }^{150}$ Parenthetically, it is ironic that similar results to those achieved by the introduction of these foreign concepts would have resulted from a use of (metropolitan) French jurisprudence. ${ }^{151}$

\section{Conclusion}

The future for uniformity of legislation in Canada is not encouraging. Under the constitution, centrifugal forces in the area of legislative competence have been dominant and, unhappily, no effective body has arisen to counteract the tendency of provincial legislatures to enact diverse legislation on most important matters. Also the factor which most promotes unity, the hierarchy of courts, is becoming of less importance as pressure is exerted for its reorganization and vital change in commercial matters become less a matter of common law and more a matter of legislation where judicial influence is least decisive. Once the bulk of legislative competence over commercial matters is given to the provinces, however, diversity in legislation is inevitable. There are three areas of importance whose unanimity is a prerequisite to uniformity: the West, Ontario, and Quebec. Unfortunately, their interests are so different in commercial matters that the likelihood of their agreement on any significant piece of legislation is remote. Quebec is in a state of political unrest caused by a feeling that its French culture is being submerged by that of the rest of the English-speaking peoples of North America; where difference is a virtue and cultural integrity a political cause, the Code civil will not be adulterated by legislative innovation. The West-Alberta, Manitoba, Saskatchewan and, to a lesser extent, British Columbia-adopts legislation which reflects its extractive economy and dominant political philosophies from both ends of the spectrum; this legislation would never be acceptable in the conservative, industrialized society of Ontario. Therefore, the attainment of interprovincial uniformity through institutional media seems impossible until these underlying societal and economic factors change.

${ }^{160}$ See Baudouin, Méthode d'interprêtation judiciare du Code civil du Québce, Io REV. DU BARR. 397, $4^{\mathrm{r} 2}$ (1950); Mignault, Le Code Civil de la Province de Québec et son Interprêtation, I U. Toronto L.J. 104 (x935).

${ }^{100}$ See Mayrand, Le droit comparé etla pensée juridique canadienne, I7 REv. DU BarR. I (I957). It is to be noted that the press of work on the court may force this very result unless it wishes to limit itself to hearing cases of national importance.

${ }_{201}$ This point is discussed in McWhinney, Legal Theory and Philosophy in Canada, in CaNadian JURISPRUDENCE 7 . 